\title{
Effects of hormones applications on the germination of six populations of Garcinia kola Heckel (Guttiferae) seeds
}

\author{
Gabriel KANMEGNE ${ }^{1 *}$ and Denis NDOUMOU OMOKOLO ${ }^{2}$ \\ ${ }^{1}$ Department of Plant Biology, Faculty of Science, University of Dschang, P.O. Box 67 Dschang, Cameroon. \\ ${ }^{2}$ Department of Biology, Higher Teacher Training College, University of Yaounde I, P.O. Box 47 Yaounde, \\ Cameroon. \\ * Corresponding author, E-mail: gkanmegne@yahoo.fr, Fax: +23733451735
}

\begin{abstract}
The present study was carried out to investigate laboratory germination responses of six collections of Garcinia kola seeds to six different hormonal pre-germination treatments. This consisted of soaking seeds for three days in cool distilled water (control), in cool distilled water supplemented with $10^{-4} \mathrm{M}$ of either naphthaleneacetic acid (NAA), 2,4-dichlorophenoxyacetic acid (2,4-D), benzylaminopurin (BAP), kinetin (Kin) or gibberellic aicid $3\left(\mathrm{GA}_{3}\right)$. The results showed that the pre-germination treatments had profound effects on the phenology of Garcinia kola seeds germination. Multiple shoots, multiple roots and callus formation were induced from seeds soaked in benzylaminopurin, naphthaleneacetic acid and 2,4-dichlorophenoxyacetic acid solutions, respectively. Analysis of variance showed a significant $(p<0.01)$ effect of seed collection on the germination velocity, indicating the variability in seed dormancy among collections. Although the rate of germination was higher in seeds treated with NAA, none of the seed treatments significantly enhanced germination when compared with the control.

(C) 2007 International Formulae Group. All rights reserved.
\end{abstract}

Keywords: Bitter kola, auxins, cytokinins, gibberellic acid, phenology, variable dormancy.

\section{INTRODUCTION}

Garcinia kola (Heckel) Fam. Guttiferae is a medium size tree (up to $12 \mathrm{~m}$ high in 8 years) found in moist forest throughout West and Central Africa (Isawumi, 1993). The bitter taste gained the seed its common name "bitter kola". It enhances the flavour of some local beverages, and plays a prominent masticatory role in traditional hospitality, cultural and social ceremonies in the southern part of Nigeria. It is an economic and highly valued tree, used extensively in African traditional medicine. Extracts of various parts of the plant are used for the treatment of laryngitis, mouth infections, cough, heart burn, liver disorder, chest colds hoarseness and others inflammatory diseases (Ainslie, 1937; Iwu, 1982). The seed is also used in the treatment of bronchitis, throat troubles, post partum haemorrhage, urinary tract infections and emesis (Irvine, 1961). Garcinia kola is known to elaborate a complex mixture of phenolic compounds including biflavonoids, xanthones, benzophenones and related triterpenes (Iwu, et al., 1990; Gieger and Quine, 1988; Waterman and Hussain, 1983). The antimicrobial activity of this plant is attributed to the benzophenones and flavanones (Hussain et al., 1982; Iwu et al., 1987). It is one of the many non-timber forest products that are of socio-economic importance. Its commercialisation in both the domestic and national markets raises the standard of living of those involved in its trading activities, both in the rural and urban centres (Adebisi, 2004).

Despite its socio-economic importance, the cultivation of the plant is very much limited. Factors that have discouraged farmers from growing Garcinia kola include 
difficulties encountered in attempting to raise seedling in nurseries. Most of the productive trees are those which were left standing when farm plots were cut out of the forest (Adebisi, 2004). During a priority setting exercise, Garcinia kola was one of the useful indigenous trees prioritised by farmers in West and Central Africa (Anegbeh et al., 2006). The regeneration conditions for the species are not well known, and the literature gives contradictory information concerning the germination of its seeds. Some authors (Okafor, 1982; Kengue and Ndo, 2003; Mbolo, 2002) describe G. kola seed as easy to germinate, while others (Gyimah, 2000; Adebisi, 2004; Anegbeh et al., 2006) describe it as exhibiting a high degree of dormancy. There have been some attempts to overcome seed dormancy and enhance germination in some Nigerian and Ghanaian collections, but the high diversity of results make it difficult to postulate a definite procedure for enhancing germination in that specie.

In Garcinia kola, seed coat is constituted of a thin leathery and waterpermeable testa surrounding the endosperm. Thus, seed dormancy in this case is not a coatimposed dormancy but may be an embryo dormancy. Many species are known where embryo dormancy can be released by hormonal treatments (Kucera et al., 2005 for review). Such information is still lacking for Garcinia kola. This study was then to determine the effect of Garcinia kola seeds pre-germination treatment with auxins (Naphthalene acetic acid and 2,4dichlorophenoxyacetic acid), cytokinins (Benzylaminopurine and Kinetin) and gibberellic acid 3 on their germination. It involved six populations of seeds, harvested from six different trees located in six different geographic areas of Cameroon, to find out whether there exists any variability in seed germination traits among individual trees.

\section{MATERIALS AND METHODS}

Six collections of seeds originating from six locations in Cameroon: Loum (Lou) in Littoral province, Yokadouma (Yok) in East province, Kumba (Kum) in South-west province, Bafia (Baf) in Centre province, Sangmelima (San) in South province and Mamfe (Mam) in South-west province, were used.
For each collection, mature seeds were harvested from a single tree in July 2006 and surface sterilised using sodium hypochlorite $(1 \%)$ for $10 \mathrm{~min}$, followed by thorough rinsing with distilled water and air drying.

Seed viability was determined using 2,3,5-triphenyl-tetrazlium chloride (TZ). The $\mathrm{TZ}$ staining procedures were adapted from the method described by the Association of Official Seed Analysts (AOSA, 2000).

Six treatments were studied for each collection. Treatments consisted in soaking seeds for three days in cool distilled water (control), or in cool distilled water supplemented with $10^{-4} \mathrm{M}$ Gibberellic acid $\left(\mathrm{GA}_{3}\right)$, Naphthalene acetic acid (NAA), 2,4dichlorophenoxyacetic acid (2,4-D), Benzylaminopurine (BAP) or Kinetin (Kin). Hormone concentration and length of time were determined in a preliminary experiment. Four replicates of 25 seeds were used per treatment for each collection.

Later, seeds from each lot were washed and placed to germinate at room temperature in $20 \mathrm{~cm}$ sterile glass petri dishes lined with two sheets of watman $\mathrm{N}^{\circ} 1$ filter paper and containing sufficient amount of distilled water. Seeds were then watered when necessary and considered to be germinated once the root or the shoot had emerged.

Percent germination was recorded at two weeks intervals for 30 weeks, and the germination index (GI) was calculated as follow: $\mathrm{GI}=($ germination $\% \div$ viability $\%) \mathrm{X}$ 100. Rate of germination was estimated by using a modified Timson's index of germination velocity: germination velocity $=$ $\Sigma \mathrm{GI} / \mathrm{t}$, where GI is the germination index at two weeks intervals and $\mathrm{t}$ is the total germination period (in weeks) (Khan and Ungar, 1997; Zia and Khan, 2004). The maximum value possible for our data using this index was 50 (i.e., 1500/30). The higher the value, the more rapid the germination.

Germination data were transformed into arcsin values before a statistical analysis was performed using statistical software package GraphPad Prism Version 3.02 for Windows. A one-way ANOVA was used to determine variability among collection and treatment means, and a Bonferroni test was used $(P<0.05)$ to determine significant differences between means of germination velocity. 


\section{RESULTS}

\section{Phenology of germination}

Pre-germination treatments studied had profound effects on the phenology of Garcinia kola seed germination. Germination of seeds in control and $\mathrm{GA}_{3}$ pre-germination treatments showed simultaneous protrusion of a radicle and a shoot apex at the two opposite ends of the ovoid-shape seed, followed by the induction of a second root at the bottom of the shoot (Fig. 1A). Seeds treated with NAA showed a single, thick and ramified root appearing first at one end of the seed (Fig. 1B), followed two to four weeks later by the protrusion of the shoot at the other end. Multiple roots (2 to 5) formation was observed in the case where roots were not thick and ramified (Fig.1C). For seeds treated with BAP or Kin, the shoot appeared at one end of the seed, followed two weeks later by the appearance of the root at the bottom of the shoot (Fig. 1D). In the case of BAP treatment, 50 percent of germinated seeds developed one to three supplementary shoots (Fig 1E). Seeds treated with 2,4-D swelled and 70 percent of them developed an undifferentiated tissue from the endosperm (Fig. 1F). Shoot or root protrusion was highly delayed and very poor in term of percentage with that pre-treatment.

\section{Rate of germination}

Analysis of variance indicated significant individual influences of seed collections (Table 1) and treatments (Table 2) on the germination rate. Seed collections could be separated in two main groups according to their germination rate: Group A comprising Lou, Yok, and San collections whose seed germination rates were significantly lower than those of Group B comprising Baf and Mam collections which performed best. Kum collection belonged to both groups since its index of germination velocity was not different neither to those of group A nor to those of group B (Fig. 2). When considering the six collections taken all round, although the germination rate was higher with seeds treated with NAA, none of the treatments studied significantly enhanced germination compared with the control (Fig. 3). Comparatively to other treatments, 2,4-D treatment significantly slowed germination.

\section{DISCUSSION}

This study shows that multiple roots, multiple shoots and callus formation could be induced in Garcinia kola seeds, by treatment with NAA, BAP and 2,4-D respectively. At least some of these roots and shoots may be adventitious instead of originating from the embryo, which is known to generate single shoot and radicle. The efficiency of NAA, BAP and 2,4-D in the induction of roots, shoots and callus formation, respectively, from tissues cultured in vitro, have been reported previously for a large range of plants (D’Amato, 1977 for review). This developmental pattern is being reported for the first time from germinating seeds. These results are an indication of the regeneration potential of the tissues of this plant, which

Table 1: One way ANOVA of index of germination velocity of six collections of Garcinia kola seeds, showing source of variation, degrees of freedom (d.f.), sum of square (S.S.), mean square (M.S.) and calculated F-value (F).

\begin{tabular}{lcccc}
\hline Source of variation & d.f. & S.S. & M.S. & F \\
\hline Collections & 5 & 1141 & 228.2 & $5.515^{* *}$ \\
Error & 30 & 1242 & 41.39 & - \\
Total & $\mathbf{3 5}$ & $\mathbf{2 3 8 3}$ & & \\
\hline
\end{tabular}

** Significant effect of collections at $1 \%$ level of probability.

Table 2: One way ANOVA of index of germination velocity of Garcinia kola seeds under six pregermination treatments, showing source of variation, degree of freedom (d.f.), sum of square (S.S.), mean square (M.S.) and calculated F-value (F).

\begin{tabular}{lcccc}
\hline Source of variation & d.f. & S.S. & M.S. & F \\
\hline Treatments & 5 & 815.8 & 163.2 & $3.124 *$ \\
Error & 30 & 1567 & 52.23 & - \\
Total & $\mathbf{3 5}$ & $\mathbf{2 3 8 3}$ & & \\
\hline * Significant effect of treatments at $5 \%$ level of probability & & &
\end{tabular}



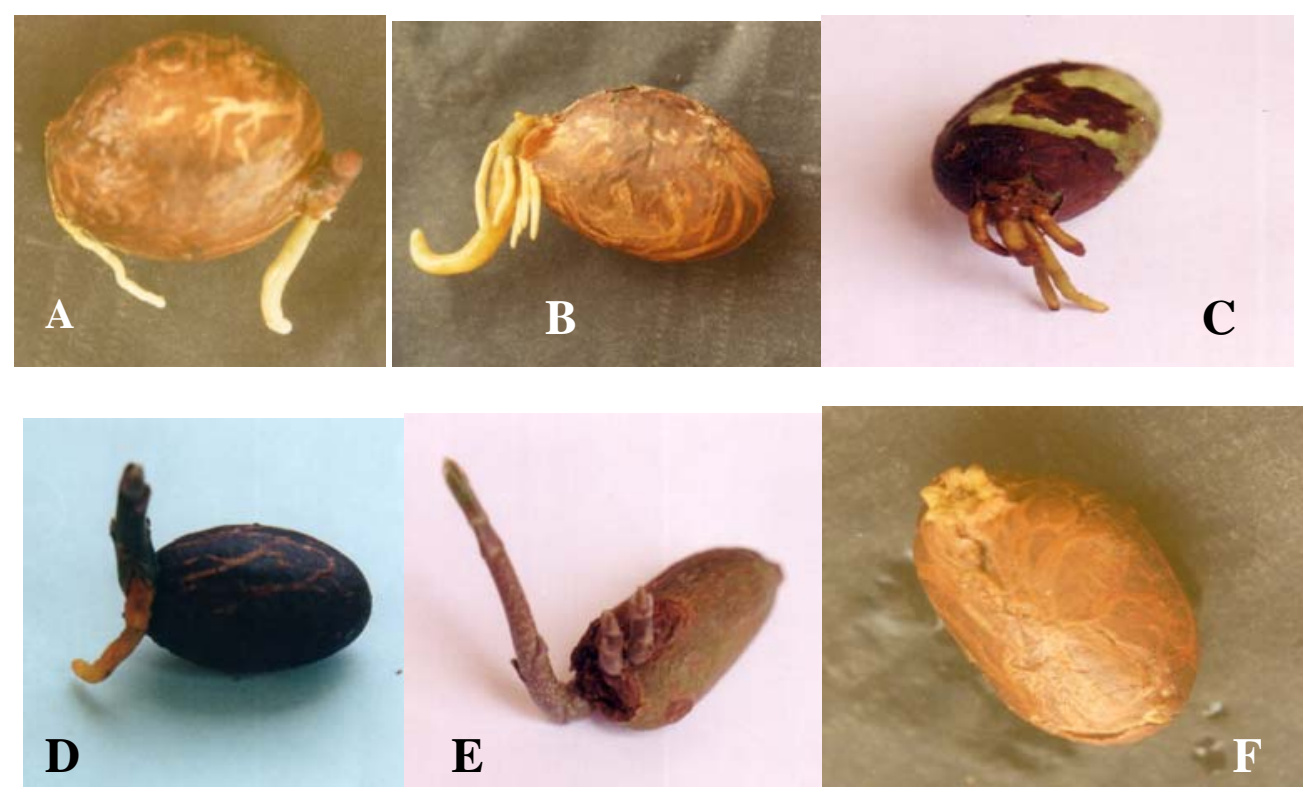

Figure 1: Effect of different pre-germination treatments on Garcinia kola seeds germination phenology. A- Protrusion of a radicle and a shoot apex at the two opposite ends of the seed and formation of a second root at the bottom of the shoot from seed soaked in distilled water supplemented or not with $10^{-4} \mathrm{M} \mathrm{GA}_{3}$. B- Single, thick and ramified root formation from seed soaked in $10^{-4} \mathrm{M}$ NAA. C- Multiple roots formation from seed soaked in $10^{-4} \mathrm{M}$ NAA. D- Appearance of a shoot and a root at the same end of the ovoid shape seed soaked in 10-4 M Kin. E- Multiple shoots formation from seed soaked in $10^{-4} \mathrm{M}$ BAP. F- Development of an undifferentiated tissue from the endosperm, at one end of seed soaked in $10^{-4} \mathrm{M} 2,4-\mathrm{D}$.

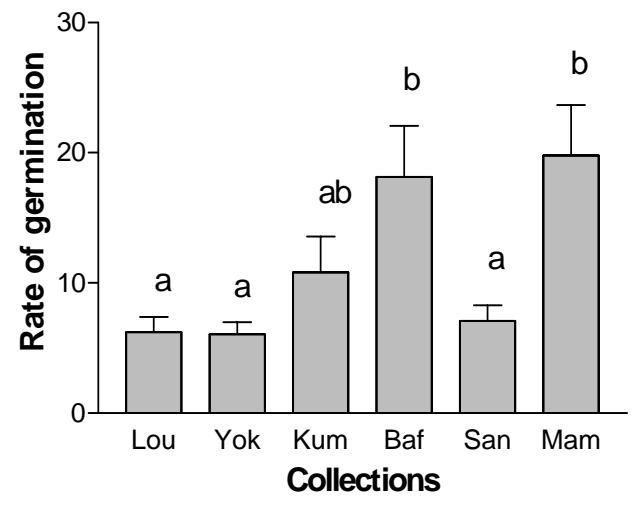

Figure 2: Germination rate of different collections of Garcinia kola seeds. Bars represent means \pm SEM of germination rates at six different pregermination treatments. Bars having the same letter are not significantly different at $\mathrm{p}<0.05$ (Bonferroni test). Lou: Loum; Yok: Yokadouma; Kum: Kumba; Baf: Bafia; San: Sangmelima; Mam: Mamfe.

propagate strictly by sexual means (Eyog et al., 2006). It would therefore be interesting to examine the conditions needed for the regeneration and multiplication of this plant through tissue culture, which could be a useful alternative for mass production of elite plants and the development of new varieties. Our

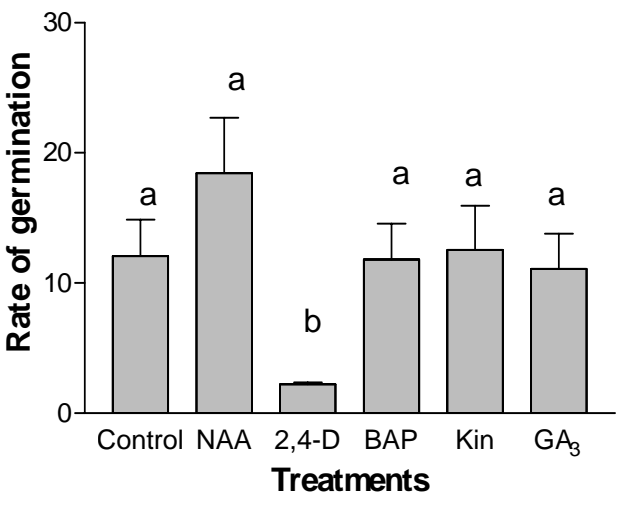

Figure 3: Germination rate of Garcinia kola seeds at different pre-germination treatments. Bars represent means \pm SEM germination rates of six collections. Bars having the same letter are not significantly different at $\mathrm{p}<$ 0.05 (Bonferroni test). $\mathrm{GA}_{3}$ : Gibberellic acid; NAA: Naphthalene acetic acid; 2,4-D: 2,4-dichlorophenoxyacetic acid; BAP: Benzylaminopurine; Kin: Kinetin.

ongoing research work is partly focused on this attempt.

Information on intraspecific variability in Garcinia kola is lacking. Our results showed significant differences in seed germination rate among the six studied collections, indicating that seed dormancy 
may be variable in the specie, but it can not been concluded which factor (topographic or climatic characteristics of locations, morphological or genetic characteristics of trees) caused these variations. Similar variations in germination traits have been found in some others tropical species such as Dalbergia sissoo and Acacia nilotica (Khurana and Singh, 2001 for review). These variations may explain the current controversy over Garcinia kola seeds germination. These results contribute to knowledge on intraspecific variation in Garcinia kola and could help in further selection and domestication processes of this specie, which has suffered neglect in the areas of research and development, despite its socio-economic importance (Adebisi, 2004). Exploiting natural variation and using less dormant seed collections as planting material could be promising tools for domestication and development of the cultivation of the species.

The cause of embryo dormancy in seeds is widely reported to be the high level of abscisic acid (ABA), a growth substance of an inhibiting nature which interrupts gene expression or evokes enzyme inhibition (Karssen et al., 1983; Berrie, 1984; Walbot et al., 1975; Fountain and Bewley, 1976). In many species, reversals of ABA inhibition of germination have been attempted by pretreating seeds with cytokinins or Gibberellins (Kucera et al., 2005 for review). Some species are known for which auxins also seem to play a prominent role in the germination process (Bialek et al., 1992; Ramaih et al., 2003). None of the growth promoters used in this work significantly increased the rate of Garcinia kola seeds germination. Results from this study are in agreement with those of Nzegbule and Mbakwe (2001), who also reported that $\mathrm{GA}_{3}$ treatment was ineffective on enhancing Garcinia kola seeds germination. This indicates that responses of seeds to exogenously applied hormones may vary with plant species. It seems, therefore, more appropriate not to make a generalization including all plants about the role of growth promoters in germination and breaking dormancy of seeds.

In relation to the variable responses given by angiosperm seeds to various growth regulator applications, Khan (1975) has proposed a model whereby, gibberellins, cytokinins and $\mathrm{ABA}$ play primary, permissive, and preventive roles, respectively, in germination. On the basis of this model, primary agent is gibberellins, and cytokinins act in the presence of ABA to remove its blockage, and gibberellin-mediated germinative processes can not occur in the presence of ABA unless there is sufficient cytokinin present to overcome its inhibitory effects. This model has been accepted by most of workers (e.g. Thomas, 1977; Berrie, 1984). There is a need, therefore, to test in further research work this Khan's hypothesis in Garcinia kola seeds, by studying the effects of associations of cytokinins and gibberellins pre-treatments of seeds on their germination. It would also be interesting to extend these studies to others chemical treatments, such as thiourea and nitrites treatments, which have shown beneficial effects in enhancing seed germination in others species (Hendricks and Taylorson, 1975; Weber et al., 1982).

\section{REFERENCES}

Adebisi AA. 2004. A case study of Garcinia kola nut production-to-consumption system in $\mathrm{J} 4$ area of Omo forest reserve, south-west Nigeria. In Forest products, livelihoods and conservation: Case studies on non-timber forest systems, Sundenland T, Ndoye O (eds). Vol. 2Africa. CIFOR : Bogor, Indonesia; 1-24.

Ainslie JR. 1937. Plants used in native medicine in Nigeria. Imperial Forestry Institute: Oxford; $42 \mathrm{p}$.

Anegbeh PO, Iruka C, Nkirika C. 2006. Enhancing germination of bitter cola (Garcinia kola) Heckel: Prospects for agroforestry farmers in the Niger delta. Scientia Africana, 5(1).

Association of Official Seed Analysts (AOSA) 2000. Tetrazolium testing handbook, Peters J (ed). Contribution $\mathrm{N}^{\circ}$ 29, New Mexico 88003.

Berrie AMM. 1984. Germination and dormancy. In: Advanced plant physiology, Wilkins MB (ed). Pitman Press: Marshfield; 440-462.

Bialek K, Michalczuk L, Cohen JD. 1992. Auxin biosynthesis during seed germination in Phaseolus vulgaris. Plant Physiol., 100: 509-517.

D'Amato F. 1977. Cytogenetics of differentiation in tissue and cell cultures. 
In Applied and fundamental aspects of plant cell, tissue and organ culture, Reinert J, Bajaj YPS (eds). SpringerVerlag: Berlin; 343-357.

Eyog MO, Ndoye O, Kengue J, Awono A. 2006. Les Fruitiers Forestiers Comestibles $d u$ Cameroun. IPGRI Regional Office for West and Central Africa; 204p.

Foutain DW, Bewley JD. 1976. Modulation of pre-germination protein synthesis by gibberellic acid, abscisic acid, and cytokinin. Plant Physiol., 58: 530-536.

Geiger H, Quine C. 1988. Biflavanoids. In The flavonoids- advances since 1980, Harbone JB (ed). Chapman and Hall: London; 99-124.

Gyimah A. 2000. Effect of pre-treatment methods on germination of Garcinia kola Heckel seeds. Ghana Journal of Forestry, 9: 39-44.

Hendricks SB, Taylorson RB. 1975. Breaking of seed dormancy by catalase inhibition. Proc. Nat. Acad. Sci., 72: 306-309.

Hussain RA, Owegby AG, Parimoo P, Waterman PG. 1982. Kolanone, a novel polyisoprenylated benzophenone with antimicrobial properties from the fruit of Garcinia kola. Planta Med., 44(2): 78-81.

Irvine FR. 1961. Woody plants of Ghana with special references to their uses. Oxford University Press: London; 145-148.

Isawumi AM. 1993. The common edible fruits of Nigeria, Part II. The Nigerian Field, 58: $1-2$.

Iwu MM. 1982. Traditional Igbo medicine. Institut of African Studies, University of Nigeria, Nsukka. 104 p.

Iwu MM, Igbokao OA, Okunji S, Tempesta MS. 1990. Antidiabetic and aldose reductase activities of biflavanones of Garcinia kola. J. Pharm. Pharmacol., 42: 290-292.

Iwu MM, Igbokao OA, Onwuchekwa U, Okunji CO. 1987. Evaluation of the antihepatotoxic activity of the biflavanoids of Garcinia kola seed. J. Ethnopharmacol., 21: 127-138.

Iwu MM, Ibokao OA, Onwuchekwa UA, Okunii CO. 1987. Evaluation of the antihepatotoxic activity of the biflavonoids of Garcinia kola seed. J. Ethnopharmacol., 21: 127-138.
Karssen CM. 1995. Hormonal regulation of seed development, dormancy and germination studied by genetic control. In Seed development and germination, Kigel J, Galili G (eds). Marcel Dekker: New York; 333-350.

Karssen CM, Brinkhorst-van der Swan DLC, Breeland AE, Koornneef M. 1983. Induction of dormancy during seed development by abscisic acid: studies on abscisic acid deficient genotypes of Arabidopsis thaliana (L.) Heynh. Planta, 157: 158-165.

Kengue J, Ndo EG. 2003. Les fruitiers comestibles du Cameroun: Aspects variabilité génétique et conservation des espèces. In Les Fruitiers Forestiers Comestibles du Cameroun, Eyog MO, Ndoye O, Kengue J, Awono A (eds). IPGRI Regional Office for West and Central Africa; 204 p.

Khan AA. 1975. Primary, preventive and permissive roles of hormones in plant systems. Bot. Rev., 41: 391-420.

Khan MA, Ungar IA. 1997. Effect of thermoperiod on recovery of seed germination of halophytes from saline conditions. Amer. J. Bot., 84: 279-283.

Kucera B, Cohn MA, Leubner-Metzger G. 2005. Plant hormone interactions during seed dormancy release and germination. Seed Sci. Res., 15: 281-307.

Kurana E, Singh JS. 2001. Ecology of tree seed and seedlings: Implication for tropical forest conservation and restoration. Current Science, 80(6): 748757.

Mbolo M. 2002. La collecte et l'analyse des données statistiques sur les produits forestiers non ligneux, étude pilote au Cameroun, Département des forêts. Programme Produits Forestiers Non Ligneux, Cameroun. 133 p.

Nzegbule E, Mbakwe R. 2001. Effect of presowing and incubation treatment on germination of Garcinia Kola (Heckel). Fruits, 56: 437-442.

Okafor JC. 1982. Essences forestières pour l'agroforesterie dans le sud du Nigeria. In Agroforesterie en Afrique tropicale humide. MacDonald LH (ed). Comptes Rendus d'un colloque tenu à Ibadan, Nigeria, 27 avril $-1^{\text {er }}$ mai 1981. Univerité des Nations Unies. 188p. 
Ramaih S, Guedira M, Paulsen GM. 2003. Relationship of indoleacetic acid and tryptophan to dormancy and preharvest sprouting of wheat. Functional Plant Biology, 30: 939-945.

Thomas TH. 1977. Cytokinins, cytokininactive compounds and seed germination. In The physiology and biochemistry of seed dormancy and germination. Khan AA (ed). North-Holland Publishing Co: Amsterdam; 111-144.

Walbot V, Clutter M, Sussex I. 1975. Effect of abscisic acid on germinating bean axes. Plant Physiol., 56: 570-574
Waterman PG, Hussain RA. 1983. Systematic significance of Xanthones, benzophenones and flavonoids in Garcinia. Biochem. Syst. Ecol., 11: 2130.

Weber GP, Wiesner LE, Lund RE. 1982. Improving germination of skunkbush sumac and serviceberry seed. J. Seed Technol., 7(1): 60-71.

Zia S, Khan MA. 2004. Effect of light, salinity, and temperature on seed germination of Limonium stocksii. Can. J. Bot., 82: 151-157. 